\title{
kshMETODE SIMPLE ADDITIVE WEIGHTING DALAM PENILAIAN GURU PNS BERPRESTASI
}

\author{
Harryanto Sofyan Anwar ${ }^{1}$, Fajar Agustini ${ }^{2}$ \\ ${ }^{1}$ Sistem Informasi, STMIK Nusa Mandiri \\ Jakarta, Indonesia \\ ${ }^{2}$ Sistem Informasi Akuntansi, Universitas Bina Sarana Informatika \\ Jakarta, Indonesia \\ e-mail: harryanto sopyan@yahoo.com, fajar.fgt@bsi.ac.id
}

\begin{abstract}
Abstrak
Penelitian ini berisi tentang penerapan penilaian guru PNS berprestasi Di SDN Kedung Jaya 02 Babelan, dimana saat ini belum adanya sistem penilaian untuk menentukan guru PNS berprestasi yang ada di SDN Kedung Jaya 02 Babelan. Oleh karena itu diperlukan sistem pendukung keputusan untuk penilaian guru PNS berprestasi. Sistem pendukung keputusan ini menggunakan metode Simple Additive Weighting (SAW). Metode ini sering dikenal dengan metode penjumlahan terbobot. Konsep dasar metode SAW adalah mencari penjumlahan nilai bobot dari rating kinerja pada setiap alternatif pada semua atribut. Kriteria yang menjadi penilaian untuk menentukan guru PNS berprestasi yang ada di SDN Kedung Jaya 02 Babelan adalah pedagogik, kepribadian, sosial dan profesional. Nilai yang lebih besar akan mengindikasikan bahwa alternative lebih terpilih. Pada kasus penilaian untuk menentukan guru PNS berprestasi yang ada di SDN Kedung Jaya 02 Babelan hasil dari penilaian dengan menggunakan metode SAW akan terlihat perbedaannya pada saat proses perangkingan saat menentukan guru PNS berprestasi.
\end{abstract}

Kata kunci: Simple Additive Weighting, Guru PNS Berprestasi, Kriteria dan Nilai Bobot

\begin{abstract}
This study contains the application of the assessment of outstanding civil servant teachers in SDN Kedung Jaya 02 Babelan, where there is currently no assessment system for determining outstanding PNS teachers in SDN Kedung Jaya 02 Babelan. Therefore we need a decision support system for the assessment of outstanding civil servant teachers. This decision support system uses the Simple Additive Weighting (SAW) method. This method is often known as the weighted sum method. The basic concept of the SAW method is to find the sum of the weighted values of the performance ratings for each alternative on all attributes. The criteria used as an assessment to determine the outstanding civil servant teachers in SDN Kedung Jaya 02 Babelan are pedagogical, personal, social and professional. A greater value will indicate that the alternative is chosen. In the case of the assessment to determine the outstanding civil servant teachers in SDN Kedung Jaya 02 Babelan the results of the assessment using the SAW method will look different during the ranking process when determining the outstanding PNS teachers.
\end{abstract}

Keywords : Simple Additive Weighting, Teacher of Civil Servant Achievement, Criteria and Weight Value 


\section{PENDAHULUAN}

Penyelenggaraan pemilihan guru PNS berprestasi di SDN Kedung Jaya 02 telah dilaksanakan sejak tahun 2009. Penyelenggaraan pemilihan guru PNS berprestasi dilaksanakan dalam beberapa jenjang pendidikan dan secara bertingkat, dimulai dari tingkat satuan pendidikan, kecamatan, kabupaten/kota, provinsi dan tingkat nasional. Secara umum, pelaksanaan pemilihan guru PNS berprestasi telah berjalan dengan lancar sesuai dengan kriteria yang ditetapkan. Namun demikian, pelaksanaannya dirasa masih belum optimal sehingga perlu dilakukan penyempurnaan sistem penyelenggaraan, khususnya pada aspek yang dinilai. (Pedoman Guru Berprestasi 2013:1-2).

Berdasarkan Pedoman Pemilihan Guru PNS Berprestasi, ada beberapa kriteria penilaian diantaranya tes tertulis, unjuk kerja/karya tulis ilmiah, wawancara, dan portofolio. Dari beberapa kriteria tersebut masing-masing memiliki bobot penilaian yang berbeda. Selain itu tiap jenjangnya memiliki kriteria yang sama dan tanpa dibatasi usia, namun bobot penilaiannya juga berbeda pula. Proses pengumpulan data dan penilaian yang dilakukan masih dilakukan secara manual dengan menggunakan Excel dan data terpisah pada tiap jenjangnya. Sehingga hal itu kurang efektif dan memungkinkan terjadinya data yang hilang.

Dalam Undang-Undang No. 14 Tahun 2005 tentang Guru mengamanatkan bahwa "Guru yang berprestasi, berdedikasi luar biasa, dan atau bertugas di daerah khusus berhak memperoleh penghargaan". Namun, dalam praktiknya, ajang Pemilihan Guru Berprestasi kurang mendapatkan respon dari para guru PNS. Menurut Johan Wahyudi dalam eduksi.kompasiana.com, 30 Mei 2013 mengatakan, "tak lagi guru bergairah mengikuti seleksi itu karena ketiadaan apresiasi sepadan dari pemerintah". Ada beberapa persoalan keengganan guru mengikuti seleksi guru PNS berprestasi. Salah satunya dalam hal besarnya pengorbanan. Pengorbanan materi maupun nonmateri untuk mengumpulkan berkas-berkas seperti portofolio, karya tulis ilmiah, dan dokumen-dokumen pribadi secara manual. Sehingga untuk meminimalisir terjadinya kendala-kendala dalam proses pemilihan Guru PNS Berprestasi, maka diperlukan suatu sistem yang mendukung dalam proses pemilihan Guru PNS Berprestasi. Merujuk pada pemikiran di atas sudah selayaknya dibangun suatu Sistem Pendukung Keputusan(SPK) yang berbasis komputer(Computer Based Decision Support System). Sistem ini adalah suatu sistem yang berbasis komputer yang ditujukan untuk membantu pengambilan keputusan dan mempunyai kemampuan analisa dalam pemilihan guru PNS berprestasi dengan memanfaatkan data dan model tertentu untuk memecahkan berbagai permasalahan. Proses pengambilan keputusan dilakukan dengan menggunakan metode Simple Additive Weighting (SAW) dengan konsep dasar metode ini adalah mencari penjumlahan terbobot dari rating kinerja pada setiap alternatif semua atribut. Dimana masing-masing kriteria sebagai faktor penilaian dan sebagai alternatif dalam hal ini adalah para guru PNS. Metode Simple Additive Weighting (SAW) merupakan metode yang paling mudah dan intuitif untuk menangani masalah multiple criteria seperti pada kasus penelitian ini, karena fungsi linear additive dapat mewakili preferensi pembuat keputusan, selain itu metode SAW juga dapat menyeleksi alternatif terbaik dari sejumlah alternatif yang ada karena terdapat proses perangkingan setelah menentukan bobot setiap atribut.

\section{Metode Pengumpulan Data}

Jurnal Sains dan Teknologi | 105 
Penelitian menggunakan data primer, berupa jawaban hasil wawancara dan memberikan kuesioner dalam hal ini kepada Kepala Sekolah dan Calon Guru

g) Komunikasi peserta didik

h) Bertindak sesuai dengan norma agama, hukum, social dan kebudayaan

FORMAT PENILAIAN SIKAP

PENENTUAN GURU BERPRESTASI

\begin{tabular}{|c|c|c|c|c|c|}
\hline Nama & : & & & & \\
\hline NIK & : & & & & \\
\hline Status & : & & & & \\
\hline \multirow{2}{*}{ No } & \multirow{2}{*}{ Kriteria Sikap } & \multicolumn{4}{|c|}{ Nilai } \\
\hline & & $\mathbf{1}$ & 2 & 3 & 4 \\
\hline 1. & Kepribadian & & & & \\
\hline 2. & Sosial & & & & \\
\hline 3. & Prosfesional & & & & \\
\hline
\end{tabular}

Berprestasi di Sekolah SDN Kedung Jaya 02. Penelitian ini menggunakan sumber data, yaitu:

\section{a. Studi Pustaka}

Pengumpulan data dengan cara mengkaji buku-buku secara teoritis yang berkaitan penelitian yang akan diteliti oleh penulis.

b. Studi Lapangan

1) Wawancara

Dilakukan untuk mendapatkan data dengan cara mewawancarai langsung Kepala sekolah yang bersangkutan dengan calon Guru Berprestasi , yaitu guru Pengajar di Sekolah SDN Kedung Jaya 02.

2) Data Nilai

Dilakukan dengan cara mendata hasil nilai calon guru PNS Berprestasi berdasarkan beberapa pengumpulan nilai berupa:
a) Menguasai teori belajar dan Prinsip-prinsip pembelajaran
b) Menguasai Karekteristik peserta didik
c) Pengembangan kurikulum
d) Kegiatan pembelajaran yang mendidik
e) Pengembangan potensi peserta didik
f) Penilaian dan Evaluasi

Nasional

i) Menunjukkan pribadian yang dewasa dan terladan

j) Etos kerja, tanggung jawab yang tinggi, rasa bangga menjadi guru

k) Bersikap inklusif, bertindak objektif, serta tidak diskriminatif

I) Komunikasi sesama guru, tenaga kependididkan, orang tua, peserta

m) Penguasaan materi, struktur, konsep dan pola pikir keilmuan yang mendukung mata pelajaran yang diampu

n) Mengembangkan keprofesionalan melaui tindakan yang reklekti

3) Form Penilaian

Dilakukan dengan cara menyerahkan Form Penilaian Sikap kepada kepala sekolah yang bersangkutan. Sedangkan data kuesioner yang diambil mencakup beberapa aspek tentang sikap:
a) Kedisiplinan
b) Kejujuran
c) Tanggung Jawab

Ketiga aspek tersebut dinilai dengan menggunakan 4 kategori pengukuran
a) Sangat Baik
b) Baik
skor 4 skor 3 
$\begin{array}{ll}\text { c) Cukup } & \text { skor } 2 \\ \text { d) Kurang } & \text { skor } 1\end{array}$

Gambar 1. Format Form Penilaian Sikap Penentuan Guru PNS Berprestasi

2. Populasi dan Sampel Penelitian

\section{a. Populasi}

Menurut Siyoto \& Sodik (2015:63)

"Populasi adalah merupakan wilayah generalisasi yang terdiri dari obyek/subyek yang memiliki kuantitas dan karakteristik tertentu yang ditetapkan oleh peneliti untuk dipelajari dan kemudian ditarik kesimpulannya.

Populasi dalam penelitian ini adalah Guru Pengajar PNS yang ada di SDN Kedung Jaya 02. Karena Guru PNS lebih di tekankan oleh Dinas Pendidikan dalam pengajaranya , maka dapat dilakukan penentuan sampel. Sampel dalam penelitian menggunakan teknik probabilitas sampel, dimana semua item pada populasi mempunyai kesempatan yang sama untuk terpilih menjadi item sampel.

b. Sampel
Menurut Siyoto \& Sodik, (2015:64) "Sampel adalah sebagian dari jumlah dan karakteristik yang dimiliki oleh populasi tersebut, ataupun bagian kecil dari anggota populasi yang diambil menurut prosedur tertentu sehingga dapat mewakili populasinya." Jika populasi besar, dan peneliti tidak mungkin mempelajari seluruh yang ada di populasi, hal seperti ini dikarenakan adanya keterbatasan dana atau biaya, tenaga dan waktu, maka oleh sebab itu peneliti dapat memakai sampel yang diambil dari populasi. Sampel yang akan diambil dari populasi tersebut harus betul-betul representatif. Sampel yang penulis ambil adalah para guru PNS berjumlah 8 guru PNS. Penulis menentukan sampel berdasarkan peringkat 1 s.d 10 tiap kelasnya. Berikut adalah sampel yang diambil:

Tabel 1. Alternatif Calon Guru PNS Berprestasi

\begin{tabular}{clc}
\hline NO & \multicolumn{1}{c}{ Nama } & NIK \\
\hline $\mathbf{1}$ & Siti Jaenabun S.Pd.I & 196702031988032002 \\
\hline $\mathbf{2}$ & Dra. Sri Sumarningsih. M.Pd & 196405202008012004 \\
\hline $\mathbf{3}$ & Rusdianan Efendi S.Pd.I & 197708202011011001 \\
\hline $\mathbf{4}$ & Sri Nani Y. S.Pd.SD & 198207112008012004 \\
\hline $\mathbf{5}$ & Padilah S. Pd.I & 197110092007011005 \\
\hline $\mathbf{6}$ & Idah Saidah S.Pd & 196710072008012003 \\
\hline $\mathbf{7}$ & Abdul Gudus Auzai. S.Pd & 198007072008011005 \\
\hline $\mathbf{8}$ & Yulianti S.Pd. SD & 108405272008012005 \\
\hline
\end{tabular}

metode analisis data yang diperlukan

3. Metode Analisis Data

\section{a. Simple Additiv Weighting} (SAW)

Berdasarkan hasil wawancara dengan

Kepala sekolah SDN Kedung Jaya 02, adalah sebagai berikut:

1) Menentukan kriteria penelitian (Ci) yang akan dijadikan acuan dalam menentukan pengambilan keputusan. 
2) Menentukan bobot preferensi atau tingkat kepentingan (W) dari setiap keriteria.

3) Menentukan rating kecocokan setiap alternative pada setiap kriteria kemudian memodelkannya ke dalam bilangan fuzzy setelah dikonversikan kebilangan crips. Pada variabel nilai diatas terdiri dari 5 bobot bilangan fuzzy yaitu:

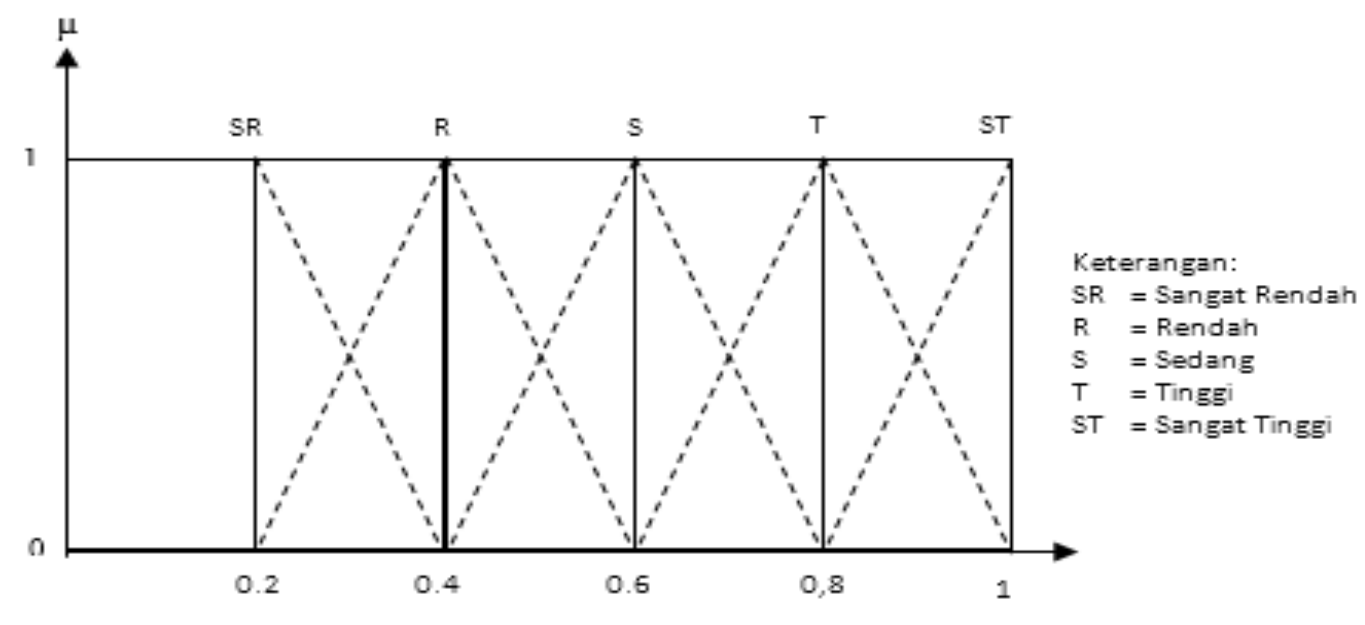

Gambar 2. Grafik Nilai Bobot Simple Additive Weighting Method Sumber : (Septiana et al, 2016)

4) Membuat matriks keputusan berdasarkan kriteria ( $\mathrm{Ci})$.

5) Melakukan normalisasi dengan cara menghitung nilai rating kinerja ternormalisasi.

6) Hasil akhir diperoleh dari proses penilaian guru berprestasi yaitu penjumlahan dari perkalian ternormalisasi $\mathrm{R}$ dengan vector bobot sehingga diperoleh nilai terbesar yang dipilih sebagai alternative terbaik (Ai) sebagai solusi. 


\section{HASIL DAN PEMBAHASAN}

\section{Pengolahan Data Simple Additive} Weighting

Berikut ini adalah langkah-langkah dalam mengolah data yang telah dikumpulkan oleh peneliti menjadi data rangking dengan menggunakan metode Simple Additive Weighting.

a. Menentukan kriteria-kriteria yang akan dijadikan acuan dalam pengambilan keputusan, yaitu $\mathbf{C} \mathbf{i}$

Setelah data diperoleh, selanjutnya adalah melakukan perhitungan dengan data tersebut dengan metode SAW. Untuk menganalisa data penilaian dari para komite sekolah dan kepala sekolah yang sudah didapatkan,

b. Melakukan Normalisasi

Selanjutnya menghitung proses normalisasi keputusan (R) ke suatu skala yang dapat diperbandingkan dengan semua rating alternative yang ada. Dimana diambil berdasarkan nilai kriteria dari masing-masing altenatif. Normalisasi alternative untuk kriteria mengembangan keprofesionalan (C14) dengan menggunakanguru persamaan $r_{i j}=\frac{X_{i j}}{M a x X_{i j}}, \quad$ karena mengembangkan keprofesionalan pada penentuan guru berprestasi masuk kategori atribut benefit. Maka dapat dilihat perhitungannya sebagai berikut: kemudian penulis mengolah sesuai dengan bobot nilai yang sudah ditentukan.

r1.14

$$
\begin{gathered}
=\frac{0,8}{\operatorname{Max}\{0,8 ; 1,0 ; 0,8 ; 1,0 ; 0,6 ; 0,6 ; 0,6 ; 1,0\}} \\
=\frac{0,8}{1,0}=0,8
\end{gathered}
$$

$$
\begin{aligned}
& r 2.14 \\
& =\frac{1,0}{\operatorname{Max}\{0,8 ; 1,0 ; 0,8 ; 1,0 ; 0,6 ; 0,6 ; 0,6 ; 1,0\}} \\
& =\frac{1,0}{1,0}=1,0
\end{aligned}
$$

\section{$r 3.14$}

$$
\begin{gathered}
=\frac{0,8}{\operatorname{Max}\{0,8 ; 1,0 ; 0,8 ; 1,0 ; 0,6 ; 0,6 ; 0,6 ; 1,0\}} \\
=\frac{0,8}{1,0}=0,8
\end{gathered}
$$

$$
\begin{aligned}
& r 4.14 \\
& =\frac{1,0}{\operatorname{Max}\{0,8 ; 1,0 ; 0,8 ; 1,0 ; 0,6 ; 0,6 ; 0,6 ; 1,0\}} \\
& =\frac{1,0}{1,0}=1,0
\end{aligned}
$$

$$
\begin{aligned}
& r 5.14 \\
& =\frac{0,6}{\operatorname{Max}\{0,8 ; 1,0 ; 0,8 ; 1,0 ; 0,6 ; 0,6 ; 0,6 ; 1,0\}} \\
& =\frac{0,6}{1,0}=0,6
\end{aligned}
$$




$$
\begin{aligned}
& r 6.14 \\
& =\frac{0,6}{\operatorname{Max}\{0,8 ; 1,0 ; 0,8 ; 1,0 ; 0,6 ; 0,6 ; 0,6 ; 1,0\}} \\
& =\frac{0,6}{1,0}=0,6
\end{aligned}
$$

$r 7.14$

$$
\begin{gathered}
=\frac{0,6}{\operatorname{Max}\{0,8 ; 1,0 ; 0,8 ; 1,0 ; 0,6 ; 0,6 ; 0,6 ; 1,0\}} \\
=\frac{0,6}{1,0}=0,6
\end{gathered}
$$

Dari keterangan diatas dapat diambil kesimpulan bahwa, setiap perhitunngan kriteria ada dua macam, jika kriteria penilaian $r 8.14$

$$
\begin{gathered}
=\frac{1,0}{\operatorname{Max}\{0,8 ; 1,0 ; 0,8 ; 1,0 ; 0,6 ; 0,6 ; 0,6 ; 1,0\}} \\
=\frac{1,0}{1,0}=1,0
\end{gathered}
$$

beratribut benefit, maka nilai kriteria penilaian dibagi dengan nilai tertinggi kemudian didapatkan

\begin{tabular}{|c|c|c|c|c|c|c|c|c|c|c|c|c|c|c|c|}
\hline \multirow[t]{2}{*}{ No. } & \multirow[t]{2}{*}{ Alternatif } & \multicolumn{14}{|c|}{ Kriteria } \\
\hline & & C1 & C2 & C3 & C4 & C5 & C6 & C7 & C8 & C9 & C10 & C11 & C12 & C13 & C14 \\
\hline 1 & SITI JAENABUN S.pd.I & 0,2 & 0,8 & 0,8 & 1,0 & 1,0 & 0,6 & 0,6 & 1,0 & 0,2 & 1,0 & 0,6 & 0,8 & 0,6 & 0,8 \\
\hline 2 & $\begin{array}{l}\text { DRA. SRI } \\
\text { SUMAMRNINGSIH M.Pd }\end{array}$ & 0,6 & 0,8 & 1,0 & 0,8 & 1,0 & 1,0 & 0,8 & 0,6 & 0,6 & 0,8 & 0,8 & 0,6 & 1,0 & 1,0 \\
\hline 3 & RUSIDIANA EFENDI S.pd.I & 1,0 & 0,4 & 0,5 & 1,0 & 0,8 & 0,8 & 1,0 & 0,6 & 0,6 & 0,8 & 0,8 & 0,8 & 1,0 & 0,8 \\
\hline 4 & SRI NANI Y S.PD.SD & 1,0 & 0,4 & 0,8 & 0,8 & 1,0 & 0,8 & 0,6 & 0,8 & 0,6 & 1,0 & 0,8 & 0,6 & 1,0 & 1,0 \\
\hline 5 & PADILAH S.PD.I & 1,0 & 0,8 & 0,8 & 0,6 & 1,0 & 1,0 & 0,6 & 0,8 & 1,0 & 0,8 & 0,8 & 0,6 & 1,0 & 0,6 \\
\hline 6 & IDAH SAIDAH S.PD & 1,0 & 0,8 & 0,8 & 0,8 & 0,8 & 1,0 & 0,8 & 1,0 & 1,0 & 1,0 & 0,8 & 0,8 & 0,8 & 0,6 \\
\hline 7 & $\begin{array}{l}\text { ABDUL GUDUS AUZIE } \\
\text { S.PD }\end{array}$ & 1,0 & 1,0 & 1,0 & 1,0 & 1,0 & 1,0 & 1,0 & 1,0 & 1,0 & 1,0 & 1,0 & 1,0 & 1,0 & 0,6 \\
\hline 8 & YULIANTI S.PD.SD & 1,0 & 1,0 & 0,8 & 1,0 & 1,0 & 1,0 & 1,0 & 1,0 & 1,0 & 1,0 & 1,0 & 1,0 & 1,0 & 1,0 \\
\hline
\end{tabular}
$\mathrm{R}$, dan jika kriteria penilaian beratribut cost, nilai terendah dibagi dengan

nilai kriteria penilaian kemudian didapatkan R.

Tabel 2 Jumlah nilai Normalisasi R untuk semua kriteria guru PNS berprestasi

c. Melakukan Perangkingan

Langkah terakhir adalah menghitung nilai bobot dari masing-masing nilai alternative berdasarkan nilai kriteria dan bobot kriteria menggunakan persamaan:

$$
V_{i}=\sum_{J-1}^{n} w_{j} r_{i j}
$$

Dimana nilai kepentingan setiap kriteria adalah sebagai berikut:

Tabel 3 Bobot Kepentingan setiap Kriteria 


\begin{tabular}{lll}
\hline c1 & $\mathbf{1}$ & sangat penting \\
\hline c2 & 0,75 & penting \\
\hline c3 & 1 & sangat penting \\
\hline c4 & 0,5 & cukup penting \\
\hline c5 & 0,75 & penting \\
\hline c6 & 1 & sangat penting \\
\hline c7 & 0,5 & cukup penting \\
\hline c8 & 0,75 & penting \\
\hline c9 & 0,75 & penting \\
\hline c10 & 0,75 & penting \\
\hline c11 & 0,75 & penting \\
\hline c12 & 0,75 & penting \\
\hline c13 & 1 & sangat penting \\
\hline & 0.5 & cukup penting \\
\hline & & \\
\hline
\end{tabular}

Berdasarkan tabel diatas, maka perhitungannya sebagai berikut:

$V 1=\{(0,2 \times 1,0)+(0,8 \times 0,75)+$ $(1,0 \times 1,0)+(1,0 \times 0,50)+(1,0 \times 0,75)+$ $(0,6 \times 1,0)+(0,6 \times 0,50)+(1,0 \times 0,75)+$ $(0,2 \times 0,75)+(1,0 \times 0,75)+(0,6 \times 0,75)+$ $(0,8 \times 0,75)+(0,6 \times 1,0)+(0,8 \times 0,50)\}=$ 7,65

$V 2=\{(0,6 \times 1,0)+(0,8 \times 0,75)+$ $(1,0 \times 1,0)+(0,8 \times 0,50)+(1,0 \times 0,75)+$ $(1,0 \times 1,0)+(0,8 \times 0,50)+(0,6 \times 0,75)+$ $(0,6 \times 0,75)+(0,8 \times 0,75)+(0,8 \times 0,75)+$ $(0,6 \times 0,75)+(1,0 \times 1,0)+(1,0 \times 0,50)\}=$ 7,9

$V 3=\{(0,2 \times 1,0)+(0,8 \times 0,75)+$ $(1,0 \times 1,0)+(1,0 \times 0,50)+(1,0 \times 0,75)+$ $(0,6 \times 1,0)+(0,6 \times 0,50)+(1,0 \times 0,75)+$ $(0,2 \times 0,75)+(1,0 \times 0,75)+(0,6 \times 0,75)+$ $(0,8 \times 0,75)+(0,6 \times 1,0)+(0,8 \times 0,50)\}=$ 8,45
$V 4=\{(1,0 \times 1,0)+(0,4 \times 0,75)+$ $(0,8 \times 1,0)+(0,8 \times 0,50)+(1,0 \times 0,75)+$ $(0,8 \times 1,0)+(0,6 \times 0,50)+(0,8 \times 0,75)+$ $(0,6 \times 0,75)+(1,0 \times 0,75)+(0,8 \times 0,75)+$ $(0,6 \times 0,75)+(1,0 \times 1,0)+(1,0 \times 0,50)\}=$ 8,6

$V 5=\{(1,0 \times 1,0)+(0,8 \times 0,75)+$ $(0,8 \times 1,0)+(0,6 \times 0,50)+(1,0 \times 0,75)+$ $(1,0 \times 1,0)+(0,6 \times 0,50)+(0,8 \times 0,75)+$ $(1,0 \times 0,75)+(0,8 \times 0,75)+(0,8 \times 0,75)+$ $(0,6 \times 0,75)+(1,0 \times 1,0)+(0,6 \times 0,50)\}=$ 9,05

$$
\begin{aligned}
V 6=\{(1,0 \times 1,0) & +(0,8 \times 0,75) \\
& +(0,8 \times 1,0)+(0,8 \times 0,50) \\
& +(0,8 \times 0,75)+(1,0 \times 1,0) \\
& +(0,8 \times 0,50)+(1,0 \times 0,75) \\
& +(1,0 \times 0,75)+(1,0 \times 0,75) \\
& +(0,8 \times 0,75)+(0,8 \times 0,75) \\
& +(0,8 \times 1,0)+(0,6 \times 0,50)\} \\
& =9,35
\end{aligned}
$$


$V 7=\{(1,0 \times 1,0)+(1,0 \times 0,75)+$

$(1,0 \times 1,0)+(1,0 \times 0,50)+(1,0 \times 0,75)+$

$(1,0 \times 1,0)+(1,0 \times 0,50)+(1,0 \times 0,75)+$

$(1,0 \times 0,75)+(1,0 \times 0,75)+(1,0 \times 0,75)+$

$(1,0 \times 0,75)+(1,0 \times 1,0)+(0,6 \times 0,50)\}=$ 10,54

$V 8=\{(1,0 \times 1,0)+(1,0 \times 0,75)+$

$(0,8 \times 1,0)+(1,0 \times 0,50)+(1,0 \times 0,75)+$

$(1,0 \times 1,0)+(1,0 \times 0,50)+(1,0 \times 0,75)+$

Tabel 4 Hasil nilai perangkingan Nilai Rata-Rata Menguasai karakterristik.

\begin{tabular}{clc}
\hline No. & \multicolumn{1}{c}{ Nama } & Nilai C1 \\
\hline $\mathbf{1}$ & SITI JAENABUN S.Pd.I & 0,2 \\
\hline $\mathbf{2}$ & Dra. SRI SUMARNINGSIH. M.Pd & 0,6 \\
\hline $\mathbf{3}$ & RUSDIANA EFENDI S.Pd.I & 1,0 \\
\hline $\mathbf{4}$ & SRI NANI Y. S.Pd.SD & 1,0 \\
\hline $\mathbf{5}$ & PADILAH S. Pd.I & 1,0 \\
\hline $\mathbf{6}$ & IDAH SAIDAH S.Pd & 1,0 \\
\hline $\mathbf{7}$ & ABDUL GUDUZ AUZAI. S.Pd & 1,0 \\
\hline $\mathbf{8}$ & YULIANTI S.Pd. SD & 1,0
\end{tabular}

Selanjutnya dapat dilihat hasil

perbandingan perangkingan antara perangkingan manual dengan SAW sebagai berikut:

Tabel 5 Hasil Perbandingan perhitungan Metode yang lama dengan SAW

\begin{tabular}{|c|c|c|c|c|c|c|}
\hline \multirow[t]{2}{*}{ No. } & \multirow[t]{2}{*}{ Nama lengkap } & \multirow{2}{*}{\multicolumn{2}{|c|}{$\begin{array}{l}\text { TOTAL Peringkat } \\
\text { MANUAL Manual }\end{array}$}} & \multirow[t]{2}{*}{ ALTERNATIF } & \multicolumn{2}{|c|}{ TOTAL Peringkat } \\
\hline & & & & & SAW & SAW \\
\hline 1 & SITI JAENABUN S.Pd.I & 48 & 7 & SITI JAENABUN S.Pd.I & 7,65 & 8 \\
\hline 2 & $\begin{array}{l}\text { Dra. SRI SUMARNINGSIH. } \\
\text { M.Pd }\end{array}$ & 54 & 3 & $\begin{array}{l}\text { Dra. SRI SUMARNINGSIH. } \\
\text { M.Pd }\end{array}$ & 7,9 & 7 \\
\hline 3 & RUSDIANA EFENDI S.Pd.I & 51 & 6 & RUSDIANA EFENDI S.Pd.I & 8,45 & 6 \\
\hline 4 & SRI NANI Y. S.Pd.SD & 52 & 5 & SRI NANI Y. S.Pd.SD & 8,6 & 5 \\
\hline 5 & PADILAH S. Pd.I & 51 & 6 & PADILAH S. Pd.I & 9,05 & 4 \\
\hline 6 & IDAH SAIDAH S.Pd & 53 & 4 & IDAH SAIDAH S.Pd & 9,35 & 3 \\
\hline
\end{tabular}




\begin{tabular}{clccccc}
\hline 7 & ABDUL GUDUZ AUZAI. S.Pd & 61 & 2 & ABDUL GUDUZ AUZAI. S.Pd & 10,54 & 2 \\
\hline 8 & YULIANTI S.Pd. SD & $\mathbf{6 2}$ & $\mathbf{1}$ & YULIANTI S.Pd. SD & $\mathbf{1 0 , 5 5}$ & $\mathbf{1}$
\end{tabular}

\section{SIMPULAN}

Berdasarkan penelitian yang dilakukan oleh penulis didapat beberapa kesimpulan diantaranya:

1. Kriteria pada data yang ada untuk penentuan siswa teladan sudah bersifat objektif dikarenakan menggunakan metode Simple Additive Weighting dimana jika bobot kriteria besar tetapi nilainya kecil akan sangat berpengaruh untuk penilaian, tetapi jika ada kekurangan pada salah satu kriteria yang bobotnya kecil maka tidak terlalu berpengaruh untuk penilaian.

2. Penentuan guru berprestasi sudah berdasarkan aspek kriteria dengan menggunakan metode Simple Additive Weighting sudah berjalan dengan baik dan dapat menghasilkan pembobotan kriteria penilaian dan informasi yang jelas dan $70 \%$ akurat dibandingkan dengan perhitungan dengan metode yang lama sehingga SDN Kedung Jaya 02 Babelan dapat mempergunakannya sebagai alat bantu dalam pengambilan keputusan yang tepat untuk menetapkan guru PNS yang berprestasi.

3. Penilaian yang sudah menggunakan simple additive weighting mengurangi timbulnya penilaian subjektif. Contoh hasil penilaian diatas, hanya posisi peringkat 1 saja yang menunjukan nama yang sama dari perhitungan metode yang lama dengan metode Simple Additive Weighting. Selebihnya berubah, contohnya Padilah S.Pd.I mendapatkan nilai 51 dengan peringkat ke 6 , sedangkan dengan

menggunakan metode Simple Additive Weighting mendapatkan nilai 9,05 memperoleh peringkat ke 4.

4. Dapat disimpulkan juga bahwa hipotesis penelitian berhasil dengan hasil $\mathrm{H} 1$ : Penulis menduga terdapat pengaruh penggunaan metode Simple Additive Weighting terhadap akurasi penentuan guru berprestasi pada SDN Kedung Jaya 02 Babelan.

\section{UCAPAN TERIMAKASIH}

Terima kasih kepada Universitas Bina Sarana Informatika dan Bapak Muhammad Rifai atas Kontribusinya dalam penulisan penelitian ini.

\section{DAFTAR PUSTAKA}

Andrianto, Christian Budi, dan Hanif Al Fatta. (2017). Analisis Sistem Pendukung Keputusan Penerima Beasiswa Di Smp Muhammadiyah 2 Kalasan. Jurnal Teknologi Informasi. Vol. 12 No. 34, 1907-2430. ISSN: 1907-2430.

Chintyari, Yananda Eka. dan Titin Prihatin (2018). Implementasi Metode Simple Additive Weighting Untuk Pemilihan Guru Berprestasi Pada SMP Islam Pondok Duta, Jurnal IImu Pengetahuan dan Teknologi Komputer. Vol. 3. No (2), 38-45. EISSN: 2527-4864.

Fauziah, Y. \& Sarjono, S. (2016). ANALISIS DAN PERANCANGAN SISTEM PENUNJANG KEPUTUSAN PEMILIHAN GURU BERPRESTASI DENGAN MENGGUNAKAN METODE SIMPLE ADDITIVE WEIGHTING(SAW) PADA SMK N1 MUARO JAMBI. Jurnal Manajemen Sistem Informasi, 1(1),35-44. 
Helilintar, Risa. Wing Wahyu Winarno dan Hanif Al-Fatta. (2016). Penerapan Metode SAW dan Fuzzy Dalam Sistem Pendukung Keputusan Penerimaan Beasiswa. Citec Journal, Vo. 3. No. (2), 89-101. ISSN: 2354-5771.

Kesuma, R. P. \& Wigati R. R. (2013). Pengembangan Sistem Penunjang Keputusan Penentuan Pemberian Beasiswa Tingkat Sekolah. JSM(Jurnal SIFO Mikroskil), 14(2), 89-98.

Mufizar, T. (2014). Sistem Pendukung Keputusan Penerimaan Mahasiswa Baru Program Beasiswa D3 TKJ Dengan Metode SAW(Simple Additive Weighting). Konferensi Nilai Niansyah, Dicky. (2014). Konsep Data Mining vs Sistem Pendukung Keputusan. Yogyakarta: Deepublish.

Naba, D. E. A.(2009). Tutorial Cepat \& Mudah Fuzzy Dengan MATLAB. Agus Naba

Nofriansyah, Dicky. (2014). Konsep Data Mining vs Sistem Pendukung Keputusan. Yogyakarta: Deepublish.

Putri, Dwi Andini. (2018). Penerapan Metode Fuzzy Saw Sebagai Pendukung Keputusan PEngangkatan Karyawan Tetap Perusahaan. Jurnal TECHNO Nusa Mandiri. Vol.15. No. (1), 31-36. ISSN: 1978-2136.

Sari, Devi. dan Oktafianto. (2017). RANCANG BANGUN SISTEM PENDUKUNG KEPUTUSAN PENENTUAN SISWA BERPRESTASI MENGGUNAKAN METODE SIMPLE ADDITIVE WEIGHTING (SAW) (STUDY KASUS SD N 01 SIDOMULYO-BANGUNREJO), Vol. 5. No. (1), 125-130.

Andrianto, Christian Budi, dan Hanif Al Fatta. (2017). Analisis Sistem Pendukung Keputusan Penerima Beasiswa Di Smp Muhammadiyah 2 Kalasan. Jurnal Teknologi Informasi. Vol. 12 No. 34, 1907-2430. ISSN: 1907-2430.
Chintyari, Yananda Eka. dan Titin Prihatin (2018). Implementasi Metode Simple Additive Weighting Untuk Pemilihan Guru Berprestasi Pada SMP Islam Pondok Duta, Jurnal IImu Pengetahuan dan Teknologi Komputer. Vol. 3. No (2), 38-45. EISSN: 2527-4864.

Fauziah, Y. \& Sarjono, S. (2016). ANALISIS DAN PERANCANGAN SISTEM PENUNJANG KEPUTUSAN PEMILIHAN GURU BERPRESTASI DENGAN MENGGUNAKAN METODE SIMPLE ADDITIVE WEIGHTING(SAW) PADA SMK N1 MUARO JAMBI. Jurnal Manajemen Sistem Informasi, 1(1),35-44.

Helilintar, Risa. Wing Wahyu Winarno dan Hanif Al-Fatta. (2016). Penerapan Metode SAW dan Fuzzy Dalam Sistem Pendukung Keputusan Penerimaan Beasiswa. Citec Journal, Vo. 3. No. (2), 89-101. ISSN: 2354-5771.

Kesuma, R. P. \& Wigati R. R. (2013). Pengembangan Sistem Penunjang Keputusan Penentuan Pemberian Beasiswa Tingkat Sekolah. JSM(Jurnal SIFO Mikroskil), 14(2), 89-98.

Mufizar, T. (2014). Sistem Pendukung Keputusan Penerimaan Mahasiswa Baru Program Beasiswa D3 TKJ Dengan Metode SAW(Simple Additive Weighting). Konferensi Nilai Niansyah, Dicky. (2014). Konsep Data Mining vs Sistem Pendukung Keputusan. Yogyakarta: Deepublish.

Naba, D. E. A.(2009). Tutorial Cepat \& Mudah Fuzzy Dengan MATLAB. Agus Naba

Nofriansyah, Dicky. (2014). Konsep Data Mining vs Sistem Pendukung Keputusan. Yogyakarta: Deepublish.

Putri, Dwi Andini. (2018). Penerapan Metode Fuzzy Saw Sebagai Pendukung Keputusan PEngangkatan Karyawan Tetap Perusahaan. Jurnal TECHNO Nusa Mandiri. Vol.15. No. (1), 31-36. ISSN: 1978-2136. 
Sari, Devi. dan Oktafianto. (2017). RANCANG BANGUN SISTEM PENDUKUNG KEPUTUSAN PENENTUAN SISWA BERPRESTASI MENGGUNAKAN METODE SIMPLE ADDITIVE WEIGHTING (SAW) (STUDY KASUS SD N 01 SIDOMULYO-BANGUNREJO), Vol. 5. No. (1), 125-130.

Subawa, I Gede Bendesa. I Made Agus Irawan dan I Made Gede Sunarya. (2015). Pengembangan Sistem Pendukung Keputusan Pemilihan Pegawai Terbaik Menggunakan Metode Simple Additive Weighting ( Saw ) Di Pt Tirta Jaya Abadi Singaraja. Kumpulan Artikel Mahasiswa Pendidikan Teknik Informatika. Vol.4. No. (5), 164-170. ISSN: 2252-9063.
Susanti, Eva. (2017). Sistem Pendukung Keputusan Penentuan Siswa Berprestasi Pada Sma Xaverius Pringsewu Menggunakan Metode Saw. Prociding KMSI, Vol.3. No. (1). Retrieved from http://ojs.stmikpringsewu.ac.id/ index.php/procidingkmsi/article/view/30 $3 / 283$

Syaiful B.(2014) Guru dan Anak Didik Dalam Interaksi Edukatif.

Zulita, L. N. (2013). Sistem Pendukung Keputusan Menggunakan Metode SAW Untuk Penilaian Dosen Berprestasi(Studi Kasus Di Universitas Dehasen Bengkulu) Jurnal Media Informatika 9(2). 